\title{
FUNDAMENTAL RESEARCH IN SAFETY GLASS
}

$\mathrm{T}$ THE Fundamental Research Laboratory of the Triplex Safety Glass Company at Holly Grange, Balsall Common, held an 'At Home' on November 14, to show the progress made since its official opening in December 1957. The main objective of the Laboratory is to establish the fundamental scientific background to safety glass manufacture and especially that of the toughened or tempered types which are produced by heat treatment. The work of the Laboratory falls roughly into four sections : toughened glass structure; physical chemistry; optics; and mechanical properties.

Work on the determination of the atomic structure of heat-treated glasses was shown in the X-ray, Electron-Microscopy and Thermodynamics Departments. Of special interest in connexion with X-ray investigations was a microdensitometer designed and built in the Laboratory.

Methods of producing safety glass by ehemical means involving ion- and atom-exchange were shown in the Physical Chemistry Laboratory. Experimental low-temperature alloys for use as bus-bar material in glasses coated with gold film were also on view.
The work displayed in the optics section included stress measurements on toughened glass using Babinet and Sénarmont methods, together with interferometric methods of measuring the thickness of thin metallic films on glass. This latter was in connexion with the use of gold films, approximately $60 \mathrm{~A}$. thick, which are used as heating elements on aircraft and other windscreens. Micro-hardness techniques to evaluate the surface properties of glass with special reference to abrasion resistance were also shown, together with apparatus for determ. ining the light transmission of aircraft windscreens.

The results of investigations towards producing safety-glass components with less scatter in mechanical properties were on view in the Heat Treatment and Mechanical Properties Departments, where the application of schlieren methods for the study of the action of air jets used in the quenching process evoked much interest. The application of strain-gauge techniques to the evaluation of stress occurring in large glasses was also demonstrated.

\section{THIRD INTERNATIONAL SEAWEED SYMPOSIUM}

\section{T} HE third International Seaweed Symposium was held in Galway, Ireland, during August 13-15, when some 220 scientists and industrialists from twenty-seven countries in Europe, Asia, Africa and the Americas attended. (The first and second Seaweed Symposia were reviewed in Nature, 170, 478 ; 1952 ; and 176,1106 ; 1955.) The symposium was opened by Mr. Seán Lemass, Minister for Industry and Commerce, who welcomed the delegates to Ireland.

Our knowledge of the physical structure of the cell-wall of many algae has been greatly increased within recent years by new techniques such as polarization microscopy, electron microscopy and X-ray diffraction analysis, and these were reviewed by Prof. R. D. Preston (England). The chemistry of the polysaccharides of the brown, red and green algae was covered by Prof. E. L. Hirst (Scotland), and Dr. H. M. Ulrich (Austria) dealt specifically with alginic acid and its derivatives both from the chemical and industrial points of view.

Nine papers were devoted to the chemistry of the carbohydrates, proteins and other constituents of the red algae. Low molecular compounds were discussed by Mr. B. Wickberg (Sweden). Further interesting glycosides have recently been isolated; for example, 'isofloridoside' is a mixture of diastereoisomers (1-O- $\alpha$-D-galactopyranosyl D- and L-glycerol), while $\mathrm{O}-\alpha$-D-galactopyranosyl $(1 \rightarrow 6)$-O- $\beta$-D-galactopyranosyl $(1 \rightarrow 1)$-glycerol, which occurs in wheat flour lipids, has been found in two red algae. Dr. J. R. Turvey (Wales) dealt with the polysaccharides of Porphyra umbilicalis, which include a galactan sulphate, floridean starch, mannan and xylan; the galactan sulphate contains D-galactose, 6-O-methylD-galactose and 3: 6-anhydro-D-galactose. $3: 6$ Anhydro-galactose is now a common constituent of red algal galactans. 6-O-Methyl D-galactose has been isolated from several Porphyra species, and Dr. J. C. $\mathrm{Su}$ (Formosa) reported its presence in $P$. crispata. The mucilage of Gloiopeltis furcata appears to be composed chiefly of agarobiose units, as in the case of the main polysaccharide ('agarose') of agar-agar. Prof. P. S. O'Colla (Ireland) discussed the constitution of the mucilage from Laurencia pinnatafida, which contains galactose, xylose, galacturonic acid and sulphate; the branched structure contains a 1 : 3-linked galactan backbone. A somewhat similar structure has been assigned to the gelatinous polysaccharide of Furcellaria fastigiata. Dr. E. G. Young (Canada) pointed out the many difficulties encountered in examining the amino-acids, peptides and proteins of Chondrus crispus ; about 20-30 per cent of the protein nitrogen could not be solubilized, but the distribution of amino-acids in this insoluble protein was similar to other algal proteins ; 80 per cent of the total nitrogen extracted was dialysable. Dr. Young also discussed the stability of carragheenin in dried C.crispus, which is of considerable importance to the seaweed industry; intrinsic viscosity and gel strength decreased markedly after storing the weed at $4^{\circ}, 10^{\circ}$ and $20^{\circ} \mathrm{C}$. for two years, indicating degradation of carragheenin in the plant. Mr. M. $O$. Reachtaire (Ireland) read a paper on phycoerythrin and phycocyanin, and the absorption spectra and structure of these chromoproteins were discussed. Dr. C. Ó hEocha (Ireland) described the occurrence and distribution among a number of red algae, particularly in the Rhodomelaceae, of four watersoluble fluorescent substances ; these were extracted, separated by chromatography, and characterized by their absorption spectra. One compound from Laurencia pinnatafida was obtained in crystalline form and its probable structure determined. 